(2) Open Access Full Text Article

\title{
Assessment of isoniazid preventive therapy in the reduction of tuberculosis among ART patients in Arba Minch Hospital, Ethiopia
}

This article was published in the following Dove Press journal:

Therapeutics and Clinical Risk Management

24 March 2017

Number of times this article has been viewed

\author{
Ashenafi Abossie \\ Tsegaye Yohanes \\ Department of Medical Laboratory \\ Sciences, College of Medicine \\ and Health Sciences, Arba Minch \\ University, Arba Minch, Ethiopia
}

Background: Tuberculosis (TB) is the most frequent life-threatening opportunistic disease among people living with HIV and remains a leading cause of mortality, even among persons receiving antiretroviral therapy (ART). Isoniazid preventive therapy (IPT) and cotrimoxazole prophylaxis have been recommended for the benefit of HIV/AIDS-infected individuals to prevent opportunistic infections. The aim of this study was to assess IPT prophylaxis in the reduction of TB among ART patients.

Methods: The study was a hospital-based retrospective study. A total of 271 study participants' available information such as demographic data, the type of prophylaxis used, and TB/ HIV coinfection status as well as other variables were collected from clinical laboratory and HIV care/ART follow-up clinic. Data analysis was performed using Statistical Package for the Social Sciences (SPSS) version 20.0.

Results: TB-infected ART patients were higher among non-IPT group (37 [27.8\%]) compared to IPT group (12 [8.7\%]). The finding showed that IPT prophylaxis significantly reduces acquiring TB with the relative risk $=0.31(95 \%$ confidence interval $=0.122,0.49)$ in ART patients of this study site where the tuberculosis prevalence is prominent. ART had significant contribution for $\mathrm{CD}^{+}{ }^{+} \mathrm{T}$-cell lymphocyte count improvement in both IPT and non-IPT groups $(P<0.05)$ in this study.

Conclusion: IPT had significant contributions to reduce the burden of TB in ART patients than non-IPT group. This result highlights the use of IPT for the prevention of TB, especially for all ART patients. Other longitudinal studies are needed to observe the benefits and side effects of IPT prophylaxis in tuberculin skin test-positive individuals.

Keywords: IPT prophylaxis, ART patients, tuberculosis, CD4 ${ }^{+}$T-cell count, opportunistic disease

\section{Background}

In 2015, there were 2.1 million (1.8-2.4 million) new HIV infections worldwide, adding to up to 36.7 million (34.0-39.8 million) people living with HIV. There were also 25.5 million (24.0-28.7 million) people living with HIV in sub-Saharan Africa, and sub-Saharan Africa accounts for almost $66 \%$ of the global total of new HIV infections. ${ }^{1}$ HIV infection is a major public health problem. The progression of HIV infection is exacerbated with coinfections such as malaria, tuberculosis (TB), and other opportunistic diseases. The existence of these coinfections and the consequences of immune interaction events deteriorate the immunocompetent capability of coinfected individuals.

TB remains the leading cause of death among people living with HIV, accounting for around one in three AIDS-related deaths. However, some progress had been made with a decline of $32 \%$ of TB-related deaths among people living with HIV
Correspondence: Tsegaye Yohanes Department of Medical Laboratory Sciences, College of Medicine and Health Sciences, Arba Minch University, PO Box: 21, Arba Minch, 1078, Ethiopia Tel +25। 912098208 Email tsegaye.yohanes@yahoo.com 
since 2004. In 2015, 10.4 million people fell ill with TB and 1.8 million died from the disease (including 0.4 million among people with HIV). Over $95 \%$ of TB, deaths also occur in low- and middle-income countries. TB patients are also the more likely to develop active TB. The risk of active TB is greater in persons with altered immune system. ${ }^{2}$ TB is a life-threatening opportunistic disease in HIV/AIDS patients, with high mortality even among patients receiving antiretroviral therapy (ART). ${ }^{3}$

The World Health Organization (WHO) estimates that one-third of the world's population is latently infected with Mycobacterium tuberculosis. Latent TB infection results when individuals infected with $M$. tuberculosis carry the organism in a latent state, which is characterized by slowed or intermittent metabolism and replication below the level necessary to produce clinical illness. ${ }^{4}$ Whereas in the general population, the lifetime risk of progression from latent TB infection to active disease is about 10\%, HIV-positive persons who are infected with $M$. tuberculosis have a 5\%-8\% annual risk and a $30 \%$ lifetime risk of developing active TB. ${ }^{5}$

TB transmission and control measure have faced challenges due to coinfection with HIV. HIV and TB service delivery is insufficiently integrated, and too many people are losing their lives because they are unable to either prevent TB or access life-saving medications for both diseases. The disease in HIV coinfected individuals also leads to high progression to AIDS. In addition, the lack of case detection problem and early treatment of TB delay the curative and as well as survival rate of coinfected individuals. ${ }^{5}$

Besides early initiation of ART, the main intervention to prevent TB in people living with HIV is isoniazid preventive therapy (IPT). Worldwide, significant progress has been made to minimize morbidity and mortality among people living with HIV/AIDS. The benefits of ART and IPT for preventing TB have been proven in adults and children in various settings. The clinical trials have shown that IPT dramatically reduces the incidence of TB among people living with HIV, including those on ART. . $^{3,6}$

Although study of cotrimoxazole (CTX) prophylaxis in HIV-infected adults with active pulmonary TB found that TMP-SMX has significantly reduced morbidity and mortality, a study from South Africa has produced evidence showing that adjunctive CTX in HIV-positive TB patients improved survival rates by $53 \% .^{7}$ However, WHO reported that IPT taken for 6-12 months reduces the risk of TB disease by $33 \%$ among all people with HIV and by $64 \%$ in HIVpositive people who have a positive tuberculin skin test. ${ }^{3}$

Currently, the use of prophylaxis for this devastating disease is more advantageous to prevent earlier the development of other opportunistic diseases, since TB is highly associated in the depletion of $\mathrm{CD}^{+}{ }^{+} \mathrm{T}$-cell count in coinfected individuals. The maximum benefits from TB preventive therapy are achieved in HIV-infected persons with evidence of TB infection as demonstrated by a positive tuberculin skin test. However, benefit has been shown among HIV-infected persons in general, regardless of their tuberculin test result. This study aimed to determine to assess the outcome of IPT prophylaxis in the prevention of TB and improvement of the immune system as determined by the $\mathrm{CD} 4^{+} \mathrm{T}$-cell count in ART patients.

\section{Methods and materials}

\section{Study area}

This study was carried out in Arba Minch hospital ART clinics. Arba Minch town is found in southern region of Ethiopia, which is $505 \mathrm{~km}$ far from Addis Ababa and $270 \mathrm{~km}$ from Hawassa, the regional capital city. Arba Minch hospital is serving a population of more than 1.7 million. Infectious diseases make up the major share of disease load in Arba Minch hospital, with malaria ranking first. The hospital provides services such as Outpatient department, Inpatient departments (medical, surgical, obstetrics, and gynecology), ophthalmology, maternal and child health, pharmacy, laboratory, and ART and TB clinics.

\section{Study design and Period}

This retrospective study included all ART patients who had been taking IPT prophylaxis from September 2010 to August 2011 in Arba Minch hospital in ART clinic. Study subjects were included by simple random sampling methods in non-IPT group and IPT group database sheets without considering the duration of ART treatment. However, selection bias was a challenge because of total number of patients who had been on IPT and fulfilled the criteria were not sufficient to be included by simple random sampling method. ART patients who were not volunteered to take IPT treatment were grouped as non-IPT group. However, those ART patients who discontinued IPT were excluded whether their TB status was positive or negative.

\section{Sample size determination}

The sample size was determined based on the prevalence of TB infection. The prevalence of TB infection is $68 \%$ in HIV coinfected individuals and $38 \%$ in non-HIV infected individuals, 95\% confidence interval, and 5\% marginal error with $80 \%$ statistical power. Considering all the above prevalence and constants, 271 individuals were estimated to be included for this study. 


\section{Data collection}

Data were collected from HIV care/ART follow-up form and registration book in ART clinic as well as laboratory data. Study subjects were included based on IPT status, and patients who had a registered baseline $\mathrm{CD} 4{ }^{+} \mathrm{T}$-cell count and full information in ART clinic were included. All ART users in the previous 1 year were assessed for coinfection, current situation, and other variables. All necessary demographic data were collected to get the whole information.

\section{Data analysis}

All raw data collected from the register were entered and analyzed using data analysis software Statistical Package for the Social Sciences (SPSS) version 20.0 (IBM Corporation, Armonk, NY, USA). This data includes sociodemographic data, cotrimoxazole and TB prophylaxis, TB status, IPT duration, and $\mathrm{CD}^{+}{ }^{+} \mathrm{T}$-cell count value. Independent sample $t$-test and bivariate statistical analysis were used. Values were also considered to be statistically significant when $P$-values are less than or equal to 0.05 .

\section{Ethical issues}

Leadership in Strategic Information Program Coordination Office (Ethiopia Public Health Association) approved the study. Arba Minch College of Health Sciences Research Affairs Ethical Committee also provided approval to collect the data and to conduct the study in Arba Minch Hospital. Written informed consent was deemed not required and waived by Arba Minch College of Health Sciences Research Affairs Ethical Committee, as all data were deidentified and kept strictly confidential. Permission was also obtained from Arba Minch Hospital Medical Directorate Office to conduct the study in the ART clinic, where the data were also deidentified and kept strictly confidential.

\section{Results \\ Description of the study participants}

Two hundred seventy one study subjects were included from both groups: IPT group had 138 (50.9\%) and non-IPT group had 133 (49.1\%). One hundred twelve (41.3\%) were male and $159(58.7 \%)$ were female. Among these study participants, $48(34.7 \%)$ and $90(65.3 \%)$ were male and female, respectively, from IPT group. Among non-IPT, 64 (48.1\%) and 69 (51.9\%) were male and female, respectively. Among the total study participants, 112 (41.3\%) were aged between 25-34 years. The mean (standard deviation [SD]) age of the participants was $31.27+12.0$, and the median age was 30 (Table 1).

Orthodox Christians constituted $176(64.9 \%)$ of the participants, followed by protestants $72(26.6 \%)$. Ninetythree $(34.3 \%)$ study participants were unable to read and write. Similarly, 95 (35.1\%) participants were educated up to a primary level. Almost half of the study participants $150(55.4 \%)$ were married, while $61(22.5 \%)$ had never married (Table 1).

\section{HIV/TB coinfection}

Two hundred seventy one study participants were randomly selected based on IPT status from ART clinics. All study participants had been taking cotrimoxazole prophylaxis. However, only 138 (50.9\%) of ART patients had been taking IPT prophylaxis for a minimum of 6 months and above. Among IPT group who have been taking the

Table I Sociodemographic characteristics of study participants on ART with prophylaxis status in Arba Minch hospital, 2010

\begin{tabular}{|c|c|c|c|c|}
\hline $\begin{array}{l}\text { Sociodemographic } \\
\text { characteristics }\end{array}$ & Group & $\begin{array}{l}\text { IPT group } \\
\text { number (\%) }\end{array}$ & $\begin{array}{l}\text { Non-IPT group } \\
\text { number (\%) }\end{array}$ & $\begin{array}{l}\text { Total } \\
\text { number (\%) }\end{array}$ \\
\hline \multirow[t]{4}{*}{ Age } & $0-14 \mathrm{yr}$ & $18(13.0)$ & $8(6.0)$ & $26(9.6)$ \\
\hline & $15-24 \mathrm{yr}$ & $13(9.4)$ & $13(9.8)$ & $26(9.6)$ \\
\hline & $25-34 \mathrm{yr}$ & $52(37.6)$ & $60(45.1)$ & $112(41.3)$ \\
\hline & $\geq 35 \mathrm{yr}$ & $50(36.2)$ & $57(42.8)$ & $107(39.5)$ \\
\hline \multirow[t]{2}{*}{ Sex } & Male & $48(34.7)$ & $64(48.1)$ & II $2(4 \mid .3)$ \\
\hline & Female & $90(65.3)$ & $69(51.9)$ & $159(58.7)$ \\
\hline \multirow[t]{3}{*}{ Religion } & Orthodox & $83(60.1)$ & $93(70.0)$ & $176(64.9)$ \\
\hline & Protestant & $37(26.8)$ & $35(26.3)$ & $72(26.6)$ \\
\hline & Others & $13(9.4)$ & $10(7.5)$ & $23(8.4)$ \\
\hline \multirow[t]{3}{*}{ Educational status } & Illiterate & $53(38.4)$ & $40(30.0)$ & $93(34.3)$ \\
\hline & Primary & $48(34.7)$ & $47(35.3)$ & $95(35.1)$ \\
\hline & Secondary and above & $32(23.1)$ & $51(38.3)$ & $83(25.8)$ \\
\hline \multirow[t]{3}{*}{ Marital status } & Single & 31 (2I.7) & $30(23.3)$ & $61(22.5)$ \\
\hline & Married & $76(53.6)$ & $74(57.1)$ & $150(55.4)$ \\
\hline & Others & $31(22.4)$ & $29(21.8)$ & $60(22.1)$ \\
\hline Total & & $138(50.9)$ & $133(49.1)$ & $271(100)$ \\
\hline
\end{tabular}

Abbreviations: ART, antiretroviral therapy; IPT, isoniazid prevention therapy; yr, year. 
Table 2 Association of sociodemographic characteristics with TB status in IPT group in Arba Minch hospital, 2010

\begin{tabular}{|c|c|c|c|c|}
\hline \multirow{2}{*}{$\begin{array}{l}\text { Sociodemographic } \\
\text { characteristics }\end{array}$} & \multirow[t]{2}{*}{ Groups } & \multicolumn{2}{|c|}{ IPT group $(n=\mid 38)$} & \multirow[t]{2}{*}{ RR (95\% Cl) } \\
\hline & & $\begin{array}{l}\text { TB positive } \\
\text { number }(\%)\end{array}$ & $\begin{array}{l}\text { TB negative } \\
\text { number }(\%)\end{array}$ & \\
\hline \multirow[t]{2}{*}{ Sex } & Male & $5(10.4)$ & $43(89.6)$ & 1.00 \\
\hline & Female & $7(7.8)$ & $83(92.2)$ & $0.75(0.25,2.23)$ \\
\hline \multirow[t]{4}{*}{ Age } & $0-14 \mathrm{yr}$ & I (I2.5) & 7 (87.75) & 1.00 \\
\hline & $15-24 y r$ & I (7.7) & $12(92.3)$ & $0.62(0.04,8.52)$ \\
\hline & $25-34 \mathrm{yr}$ & $3(5.0)$ & $57(95.0)$ & $0.40(0.05,3.4)$ \\
\hline & $\geq 35 \mathrm{yr}$ & $7(12.3)$ & $50(87.7)$ & $0.98(0.14,6.98)$ \\
\hline \multirow[t]{3}{*}{ Marital status } & Single & $3(9.7)$ & $28(90.3)$ & 1.00 \\
\hline & Married & $5(6.6)$ & 7I (93.4) & $0.68(0.17,2.67)$ \\
\hline & Others & $4(12.9)$ & $27(87.1)$ & $1.33(0.32,5.47)$ \\
\hline \multirow[t]{3}{*}{ Educational status } & Illiterate & $3(7.5)$ & $37(92.5)$ & 1.00 \\
\hline & Primary & $7(14.9)$ & $40(85.1)$ & $2.15(0.5 I, 8.96)$ \\
\hline & Secondary and above & $2(3.9)$ & $49(96.1)$ & $0.52(0.09,2.98)$ \\
\hline \multirow[t]{3}{*}{ Religion } & Orthodox & $9(9.7)$ & $84(90.3)$ & 1.00 \\
\hline & Protestant & $2(5.7)$ & $33(94.3)$ & $0.59(0.13,2.60)$ \\
\hline & Others & I (I0.0) & $49(90.0)$ & $1.03(0.15,7.34)$ \\
\hline Total & & $12(8.7)$ & $126(91.3)$ & \\
\hline
\end{tabular}

Abbreviations: $\mathrm{Cl}$, confidence interval; TB, tuberculosis; IPT, isoniazid prevention therapy; RR, relative risk; yr, year.

prophylaxis, $12(8.7 \%)$ of the study participants were infected by TB, whereas the remaining $126(91.3 \%)$ study participants were TB negative after 6 months duration on IPT (Table 2).

As shown in Table 2, among IPT group in univariate analysis, primary educational level had higher possibility to acquire TB infection compared to the illiterate (relative risk $[\mathrm{RR}]=2.15 ; 95 \%$ confidence interval $[\mathrm{CI}]=0.51,8.96)$. Out of the 133 participants also in the non-IPT group, 19 (14.2\%) males and $18(13.5 \%)$ females were coinfected with TB. And about 37 (27.8\%) participants had acquired TB infections.
In the non-IPT group, age, religion, and educational level played a more significant role in acquiring TB infection compared with their reference values, as shown in Table 3.

As Table 4 shows, IPT prophylaxis users were protected from TB infection with statistically significant difference compared with those who did not use IPT prophylaxis $(\mathrm{RR}=0.32 ; 95 \% \mathrm{CI}=0.122,0.49)$ in this study.

\section{CD4 ${ }^{+} \mathrm{T}$-cell count profile}

Out of 138 cases of IPT group, 86 (62.3\%) checked their $\mathrm{CD}^{+}$count status, and the remaining percentage of study

Table 3 Association of sociodemographic characteristics with TB status in non-IPT group in Arba Minch hospital, 2010

\begin{tabular}{|c|c|c|c|c|}
\hline \multirow{2}{*}{$\begin{array}{l}\text { Sociodemographic } \\
\text { characteristics }\end{array}$} & \multirow[t]{2}{*}{ Groups } & \multicolumn{2}{|c|}{ Non-IPT group $(n=133)$} & \multirow[t]{2}{*}{$\operatorname{RR}(95 \% \mathrm{Cl})$} \\
\hline & & $\begin{array}{l}\text { TB positive } \\
\text { number (\%) }\end{array}$ & $\begin{array}{l}\text { TB negative } \\
\text { number (\%) }\end{array}$ & \\
\hline \multirow[t]{2}{*}{ Sex } & Male & $19(29.7)$ & $45(70.3)$ & 1.00 \\
\hline & Female & $18(26.1)$ & 51 (73.9) & $0.88(0.5 \mathrm{I}, \mathrm{I} .52)$ \\
\hline \multirow[t]{4}{*}{ Age } & $0-14 \mathrm{yr}$ & $6(33.3)$ & $12(66.7)$ & 1.00 \\
\hline & $15-24 \mathrm{yr}$ & $4(30.8)$ & $9(69.2)$ & $0.92(0.32,2.62)$ \\
\hline & $25-34 \mathrm{yr}$ & $13(25.0)$ & $39(75.0)$ & $0.75(0.34,1.68)$ \\
\hline & $\geq 35 \mathrm{yr}$ & $14(28.0)$ & $36(72.0)$ & $0.84(0.38,1.85)$ \\
\hline \multirow[t]{3}{*}{ Marital status } & Single & $9(30.0)$ & $21(70.0)$ & 1.00 \\
\hline & Married & $17(23.0)$ & $57(77.0)$ & $0.77(0.38,1.52)$ \\
\hline & Others & II (37.9) & $18(62.1)$ & $1.26(0.62,2.59)$ \\
\hline \multirow[t]{3}{*}{ Educational status } & Illiterate & $15(28.3)$ & 38 (7I.7) & 1.00 \\
\hline & Primary & 14 (29.2) & $34(70.8)$ & $1.03(0.56,1.96)$ \\
\hline & Secondary and above & $8(25.0)$ & $24(75.0)$ & $0.88(0.42,1.85)$ \\
\hline \multirow[t]{3}{*}{ Religion } & Orthodox & $21(25.3)$ & $62(74.4)$ & 1.00 \\
\hline & Protestant & $9(6.7)$ & $28(21.0)$ & $0.96(0.49,1.89)$ \\
\hline & Others & $7(53.8)$ & $6(46.2)$ & $2.13(1.14,3.97)$ \\
\hline Total & & 37 (27.8) & $96(72.2)$ & \\
\hline
\end{tabular}

Abbreviations: $\mathrm{Cl}$, confidence interval; TB, tuberculosis; IPT, isoniazid prevention therapy; RR, relative risk; yr, year. 
Table 4 TB status with prophylaxis type used among patients on ART in Arba Minch hospital, 2010

\begin{tabular}{llll}
\hline \multirow{2}{*}{$\begin{array}{l}\text { Type of } \\
\text { prophylaxis }\end{array}$} & \multicolumn{2}{l}{ AFB smear result } & RR $(\mathbf{9 5 \%} \mathbf{~ C l})$ \\
\cline { 2 - 3 } & $\begin{array}{l}\text { Positive } \\
\text { number (\%) }\end{array}$ & $\begin{array}{l}\text { Negative } \\
\text { number (\%) }\end{array}$ & \\
\hline IPT group & $12(8.7)$ & $126(91.3)$ & $0.32(0.122,0.49)$ \\
Non-IPT group & $37(27.8)$ & $96(72.2)$ & \\
Total & $49(18.0)$ & $222(82.0)$ & \\
\hline
\end{tabular}

Abbreviations: ART, antiretroviral therapy; $\mathrm{AFB}$, acid-fast bacillus; $\mathrm{Cl}$, confidence interval; TB, tuberculosis; IPT, isoniazid prevention therapy; RR, relative risk.

subjects did not get the opportunity to check $\mathrm{CD} 4^{+} \mathrm{T}$-cell count because of the problem with the automated machine, shortage of reagents, etc. Among non-IPT group, only 54 (40.6\%) study subjects' CD4 $4^{+}$count values were obtained with two intervals. With independent sample $t$-test statistical analysis, at the baseline, both groups' mean $\mathrm{CD} 4^{+} \mathrm{T}$-cell count value was not significantly different. Therefore, it was comparable at baseline $(P=0.5)$. The difference was not significantly different $(P=0.2)$ after 6 months. However, the mean $\mathrm{CD} 4^{+}$count showed an improvement in IPT group and non-IPT group ART patients after 6 months. Both the IPT group and non-IPT group had significant $\mathrm{CD} 4^{+} \mathrm{T}$-cell count improvement. This might be due to use of ART treatments for $\mathrm{CD}^{+} \mathrm{T}$-cell count improvements (Table 5).

\section{Discussion}

In countries where TB is common, many people have been exposed to TB and have a latent infection. The WHO recommends the use of IPT in HIV-infected patients in countries with high prevalence of HIV infection. IPT can prevent latent TB infection from developing into active disease. A 6-month course of IPT reduces the risk of getting TB for people living with HIV by $33 \% .{ }^{8}$ This study assessed the outcome of IPT prophylaxis in the reduction of TB among ART patients. Furthermore, the study also evaluated ART benefit to improve the immune status of ART patients.

Table 5 Mean $\mathrm{CD}^{+}$count change, with prophylaxis type, among ART users from Arba Minch hospital, Ethiopia, 2010

\begin{tabular}{llll}
\hline Period & $\begin{array}{l}\text { IPT group } \\
(\mathbf{n}=\mathbf{8 6})\end{array}$ & $\begin{array}{l}\text { Non-IPT group } \\
(\mathbf{n}=\mathbf{5 4})\end{array}$ & P-value \\
\hline $\begin{array}{l}\text { Mean CD4+ count (SD) } \\
\text { At the baseline }\end{array}$ & $267.66(146.59)$ & $252.4 I(179.4 I)$ & 0.5 \\
$\begin{array}{l}\text { Mean CD4 } \\
\text { After 6 mo }\end{array}$ & $389.55(221.09)$ & $346.04(245.32)$ & 0.2 \\
$P$-value & 0.00 & 0.01 & \\
\hline
\end{tabular}

Abbreviations: ART, antiretroviral therapy; IPT, isoniazid preventive therapy; SD, standard deviation; mo, month.
In this study, about half of the study participants were aged between 25 and 34 years old. In agreement with the survey of Ethiopia Demographic and Health Survey 2005, higher magnitude of HIV was found in this age group. Furthermore, the majority of study participants were married, similar to the surveillance reports of Ethiopia. ${ }^{9}$

Consistent with this study, a study from Brazil found that IPT and ART were both effective in reducing TB risk in HIVinfected adults. ${ }^{10}$ This finding agreed with others that showed the benefit of IPT combined to ART to reduce TB risk in HIVinfected patients. ${ }^{11}$ Overall, the combination of the two interventions was considerably more protective than either alone.

ART alone in non-IPT group had an effect on the improvement of $\mathrm{CD}^{+}{ }^{+} \mathrm{T}$-cell count with statistically significant difference in this study. Consistent with other studies, ART alone reduces the risk of TB. ${ }^{12,13}$ This could be due to the benefit ART in suppression of viral load and restoration of the immune status of the patients that prevent opportunistic diseases. However, the proportion of TB coinfected participants was higher among non-IPT group than IPT group in this study.

Both IPT and ART are associated with reduced TB, and patients had higher $\mathrm{CD} 4^{+} \mathrm{T}$-cell count in this study. Although M. tuberculosis can activate HIV-infected $\mathrm{CD} 4^{+}$lymphocytes and lead to progression from HIV infection to clinical AIDS, the wider use of IPT and combination with ART in patients with HIV can improve TB prevention in high-burden areas. ${ }^{14}$ Additionally, there is also a WHO recommendation that shows that IPT given for 6-12 months after TB treatment is effective in reducing the risk of recurrent TB disease. ${ }^{15}$

In addition, in agreement with Walker et al ${ }^{16}$ evidence from the data has shown that CTX therapy reduces mortality among persons with HIV. Thus, this preventive therapy contribution to reduce TB infection by preventing the decline of $\mathrm{CD} 4^{+} \mathrm{T}$-cell count in the study participants.

At baseline, $\mathrm{CD} 4^{+} \mathrm{T}$-cell counts were lower in the cases of IPT/ART group and ART alone compared with 6 months later. The preventive therapy and ART drugs had an effect on increasing $\mathrm{CD} 4^{+} \mathrm{T}$-cell lymphocyte count, and even patients on ART alone had much better immune restoration. ${ }^{17}$ In addition, since ART supports the participants mean $\mathrm{CD}^{+}$count improvement, this might have contributions to prevent active TB.

\section{Limitations}

This study has several limitations; the tuberculin skin test was not done on the study participants and there was a missing data, and WHO staging as well as ART duration was not evaluated since it was a retrospective study. 


\section{Conclusion}

IPT in conjunction with ART had a significant contribution in reducing $\mathrm{TB}$ infection and $\mathrm{CD} 4^{+} \mathrm{T}$-cell count improvements. Improvement of $\mathrm{CD}^{+} \mathrm{T}$-cell count might be occurring due to ART in both IPT and non-IPT group. Therefore, IPT combined with ART is valuable to prevent reactivation/ exogenous infection of TB in ART patients. Other longterm studies are recommended to assess the effect of IPT prophylaxis on ART patients.

\section{Acknowledgments}

This research was supported by Center for Disease Control and Prevention, Ethiopia and Ethiopian Public Health Association (EPHA) in the leadership in strategic information (LSI) program. We would like to thanks EPHA for financial supports and instructors of Community Health Department, Addis Ababa University for advisory. We also thank the Arba Minch College of Health Sciences for their support in the study. We acknowledge Arba Minch Hospital ART clinic and Medical laboratory staffs for their support in data collection.

\section{Author contributions}

AA has contributed to conception of the study question, designed the study, collected data, analyzed data, interpreted data, and drafted the manuscript, and TY has involved in data collection, data analysis, data interpretation, and drafting of the manuscript. Both authors agree to be accountable for all aspects of the work.

\section{Disclosure}

The authors report no conflicts of interest in this work.

\section{References}

1. UNAIDS. World AIDS Day, 2015. Global Statistics. UNAIDS; 2015.

2. World Health Organization. Global Tuberculosis Fact sheet 2016. Geneva: World Health Organization; 2017.

3. WHO. Joint HIV and TB Department Meeting. Report from WHO's Three I's Meeting: intensified case finding (ICF), isoniazid preventive therapy (IPT) and TB infection control (IC) for people living with HIV. Geneva, Switzerland: WHO; 2008.
4. Manabe YC, Bishai WR. Latent Mycobacterium tuberculosis persistence, patience, and winning by waiting. Nat Med. 2000;6: 1327-1329.

5. Selwyn PA, Hartel D, Lewis VA. A prospective study of the risk of tuberculosis among intravenous drug users with human immunodeficiency virus infection. $N$ Eng $J$ Med. 1989;320:545-550.

6. Mermin J, Ekwaru JP, Liechty CA, Were W, Downing R, Ransom R. Effect of cotrimoxazole prophylaxis, antiretroviral therapy, and insecticidetreated bednets on the frequency of malaria in HIV-1-infected adults in Uganda: a prospective cohort study. Lancet. 2006;367:1256-1261.

7. Badri M, Maarten G, Wood R, Ehrlich R. Cotrimoxazole and HIV-1 infection. Lancet. 1999;354:334-335.

8. World Health Organization. Global Tuberculosis Control: Epidemiology, Strategy, Financing. Available from: http://www.who.int/tb/ publications/globalreport/2009/en/. Accessed July 27, 2009.

9. Central Statistical Agency and ORC Macro. Ethiopia Demographic and Health Survey 2005. Ethiopia \& Maryland: Central Statistical Agency and ORC Macro; 2006. Available from: http://www.dhsprogram.com/ pubs/pdf/FR179/FR179[23June2011].pdf. Accessed November 15, 2016.

10. Golub JE, Saraceni V, Cavalcante SC, Pacheco AG, Moulton LH, King BS. The impact of antiretroviral therapy and isoniazid preventive therapy on tuberculosis incidence in HIV-infected patients in Rio de Janeiro, Brazil. AIDS. 2007;21:1441-1448.

11. Badri M, Wilson D, Wood R. Effect of highly active antiretroviral therapy on incidence of tuberculosis in South Africa: a cohort study. Lancet. 2002;359(9323):2059-2064.

12. Lawn SD, Wood R, De Cock KM, Kranzer K, Lewis JJ, Churchyard GJ. Antiretroviral and isoniazid preventive therapy in the prevention of HIVassociated tuberculosis in settings with limited health-care resources. Lancet Infect Dis. 2010;10(7):489-498.

13. Rangaka MX, Boulle A, Wilkinson RJ, et al. Randomized controlled trial of isoniazid preventive therapy in HIV-infected persons on antiretroviral therapy. Poster Presented at: 19th International AIDS Conference; July 22-27; 2012; Washington, DC, USA.

14. Fitzgerald D, Morse MM, Pape JW, Johnson WD. Active tuberculosis in individuals infected with human immunodeficiency virus after isoniazid prophylaxis. Jr CID. 2000;31:1495-1497.

15. World Health Organization. Guidelines for Intensified Tuberculosis Case Finding and Isoniazid Preventive Therapy for People Living with HIV in Resource-Constrained Settings. Geneva, Switzerland: World Health Organization; 2011. Available from: http://www.who.int/hiv/ pub/tb/9789241500708/en/. Accessed March 24, 2014.

16. Walker AS, Ford D, Gilks CF, et al. Daily co-trimoxazole prophylaxis in severely immunosuppressed HIV-infected adults in Africa started on combination ART: an observational analysis of the DART cohort. Lancet. 2010;375:1278-1286.

17. Brouwer M, Gudo PS, Simbe CM, Perdigão P, van Leth F. The effect of tuberculosis and antiretroviral treatment on $\mathrm{CD} 4+$ cell count response in HIV-positive tuberculosis patients in Mozambique. BMC Public Health. 2012;12:670.
Therapeutics and Clinical Risk Management

\section{Publish your work in this journal}

Therapeutics and Clinical Risk Management is an international, peerreviewed journal of clinical therapeutics and risk management, focusing on concise rapid reporting of clinical studies in all therapeutic areas, outcomes, safety, and programs for the effective, safe, and sustained use of medicines. This journal is indexed on PubMed Central, CAS,

\section{Dovepress}

EMBase, Scopus and the Elsevier Bibliographic databases. The manuscript management system is completely online and includes a very quick and fair peer-review system, which is all easy to use. Visit http://www.dovepress.com/testimonials.php to read real quotes from published authors. 